\title{
Paralytic shellfish toxins (PSTs) and tetrodotoxin (TTX) of Korean pufferfish
} \author{
Ji Hoe Kim ${ }^{4}$ \\ ${ }^{1}$ Food Safety and Processing Research Division, National Institute of Fisheries Science, Busan 46083, Korea \\ ${ }^{2}$ Southeast Sea Fisheries Research Institute, National Institute of Fisheries Science, Tongyeong 53085, Korea \\ ${ }^{3}$ South Sea Fisheries Research Institute, National Institute of Fisheries Science, Yeosu 59780, Korea \\ ${ }^{4}$ Research and Development Planning Division, National Institute of Fisheries Science, Busan 46083, Korea
}

Ka Jeong Lee ${ }^{1, *}$, Kwang Soo Ha ${ }^{2}$, Yeoun Joong Jung ${ }^{1}$, Jong Soo Mok ${ }^{3}$, Kwang Tae Son ${ }^{1}$, Hee Chung Lee ${ }^{1}$,

\begin{abstract}
Paralytic shellfish toxins (PSTs) and tetrodotoxin (TTX) are neurotoxins that display pharmacological activity that is similar to that of specific sodium channel blockers; they are the principle toxins involved in shellfish and puffer fish poisoning. In Korea, puffer fish is a very popular seafood, and several cases of accidental poisoning by TTX have been reported. Therefore, it is necessary to determine whether puffer fish poisoning incidents are caused by PSTs or by TTX. In this study, we used mouse bioassay (MBA) and liquid chromatograph-tandem mass spectrometry (LC-MS/MS) to determine the presence of PSTs and TTX in puffer fish from an area near Mireuk-do, Tong-Yeong on the southern coast of Korea from January through March, 2014. The toxicity of PSTs and TTX extracts prepared from three organs of each specimen was analyzed by MBA. Most of the extracts killed mice with typical signs of TTX and PSTs. The LC-MS/MS analysis of seven specimens of Takifugu pardalis and Takifugu niphobles, each divided into muscles, intestines, and liver, were examined for TTX. In T. pardalis, the TTX levels were within the range of 1.3-1.6 $\mu \mathrm{g} / \mathrm{g}$ in the muscles, $18.8-49.8 \mu \mathrm{g} / \mathrm{g}$ in the intestines, and $23.3-96.8 \mu \mathrm{g} / \mathrm{g}$ in the liver. In T. niphobles, the TTX levels were within the range of $2.0-4.5 \mu \mathrm{g} / \mathrm{g}$ in the muscles, $23.9-71.5 \mu \mathrm{g} / \mathrm{g}$ in the intestines, and $28.1-114.8 \mu \mathrm{g} / \mathrm{g}$ in the liver. Additionally, the toxicity profile of the detected PSTs revealed that dcGTX3 was the major component in T. pardalis and T. niphobles. When PSTs were calculated as saxitoxin equivalents the levels were all less than $0.5 \mu \mathrm{g} / \mathrm{g}$, which is below the permitted maximum standard of $0.8 \mu \mathrm{g} / \mathrm{g}$. These findings indicate that the toxicity of T. pardalis and T. niphobles from the southern coast of Korea is due mainly to TTX and that PSTs do not exert an effect.
\end{abstract}

Keywords: Takifugu niphobles, Takifugu pardalis, Tetrodotoxin, Paralytic shellfish toxin, Pufferfish

\footnotetext{
Received: Aug 2, 2021 Revised: Sep 24, 2021 Accepted: Sep 25, 2021

${ }^{\star}$ Corresponding author: Ka Jeong Lee

Food Safety and Processing Research Division, National Institute of Fisheries Science, Busan 46083, Korea

Tel: +82-51-720-2636, Fax: +82-51-720-2619, E-mail: kajlee@korea.kr
}

This is an Open Access article distributed under the terms of the Creative Commons Attribution Non-Commercial License (http://creativecommons.org/licenses/by$\mathrm{nc} / 4.0 /$ ) which permits unrestricted non-commercial use, distribution, and reproduction in any medium, provided the original work is properly cited.

Copyright $\odot 2021$ The Korean Society of Fisheries and Aquatic Science 


\section{Introduction}

Paralytic shellfish toxins (PSTs) are the principal cause of only one type of shellfish poisoning. There are several additional shellfish related marine toxin syndromes such as amnesic shellfish poisoning, neurotoxin shellfish poisoning, diarrhetic shellfish poisoning, etc.

Paralytic shellfish poisoning is only one type of shellfish poisoning caused by the accumulation of toxins from dinoflagellates.

In humans, poisoning through the consumption of toxin-bearing shellfish induces paralysis (Bricelj \& Shumway, 1998; Mortensen, 1985). It is true that certain species of cyanobacteria produce toxins, even saxitoxin, but these typically occur in freshwater and are more of a concern for drinking water. The majority of toxins that accumulate in shellfish are from dinoflagellates of marine origin.

In addition to bivalves, PSTs have also been detected in non-filter-feeding gastropods (Itoi et al., 2012), crustaceans (Negri \& Llewellyn, 1998), and zooplanktivorous fish (Sephton et al., 2007; White, 1981). Typically, these species accumulate toxins through the food web (White, 1981). Several studies have shown that puffer fish also accumulate PSTs (Abbott et al., 2009; Kodama et al., 1983; Nakashima et al., 2004; Sato et al., 2000).

TTX is structurally different from PSTs, although both are low molecular weight neurotoxins that block sodium channels. The stimulated nerves are therefore unable to generate action potentials, which then leads to paralysis (Kao, 1986). Because this mechanism of action is common to both PSTs and TTX, it is necessary to determine whether puffer fish poisoning is caused by PSTs or by TTX.

In both Korea and the rest of the world, PST poisoning is considered a major public health problem. In addition to PSTs, TTX has a very high fatal dose and is considered to be critical in food hygiene. Food poisoning from puffer fish has also become a social problem in Korea, resulting in fatalities every year (Kim et al., 2003).

In the current study, we focused on the puffer fish, which is a popular fishery product in Korea. Specifically, we studied Takifugu pardalis and Takifugu niphobles, which are known to be highly toxic. Mouse bioassay (MBA) and liquid chromatography-tandem mass spectrometry (LC-MS/MS) were employed to analyze TTX and PSTs in puffer fish, and the effects of these toxins were examined.

\section{Materials and Methods}

\section{Reagents and standard toxins}

For the analysis of PSTs and TTX were used to prepare the standard solutions of PSTs, i.e., C1, C2, dcGTX2, dcGTX3, dcSTX, GTX1, GTX2, GTX3, GTX4, GTX5, NEO, STX (Marine Biosciences of the National Research Council, Halifax, NS, Canada) and tetrodotoxin (Alomone Labs, Jerusalem, Israel). High performance liquid chromatography (HPLC) grade solvents acetonitrile, methanol (Merck, Darmstadt, Germany) and an analytical grade reagent hydrochloric acid (Merck) were used for preparation of the analysis sample solution and mobile phase. In addition, mass spectrometry grade reagents formic acid, ammonium formate (Fluka, Buchs, Germany) were used for the preparation of HPLC mobile phases. Analytical grade reagents trichloroacetic acid (TCA), sodium hydroxide, and acetic acid were purchased from Sigma (St. Louis, MO, USA) and deionized water was passed through a Milli-Q water purification system (Millipore, Bedford, MA, USA).

\section{Field sampling}

Takifugu pardalis and Takifugu niphobles samples were collected once per month using a fixed set net along Mireuk-do, Tong-Yeong of Korea from January through March, 2014. Harvested fish were stored chilled, typically for less than $24 \mathrm{~h}$ prior to testing and dissection of the muscle, intestines, and liver of individuals. These individual samples were kept frozen at $-20^{\circ} \mathrm{C}$ prior to toxin analysis.

\section{Sample extractions}

PSTs were extracted from 5-g samples of homogenized tissue following the Association of Official Analytical Chemists (AOAC) method (AOAC, 2005) using $5 \mathrm{~mL}$ of $0.1 \mathrm{~N} \mathrm{HCl}$. These sample extracts were deproteinated for LC-MS/MS analysis, and $25 \mu \mathrm{L}$ of $30 \%(w / v)$ TCA was added to $500 \mu \mathrm{L}$ of sample extract in a microcentrifuge tube, then mixed in a vortex mixer and centrifuged at $7,000 \times \mathrm{g}$ for $5 \mathrm{~min}$. Next, $20 \mu \mathrm{L}$ of $1.0 \mathrm{M}$ $\mathrm{NaOH}$ was added to neutralize the solution, which was mixed and centrifuged again. Finally, the solution was filtered through a $0.2 \mu \mathrm{m}$ syringe filter (Adventec, Tokyo, Japan) into an autosampler vial in preparation for LC-MS/MS analysis by boiling for $10 \mathrm{~min}$ and centrifuging at $7,000 \times \mathrm{g}$ for $10 \mathrm{~min}$ at $4^{\circ} \mathrm{C}$. The supernatant was filled up to $10 \mathrm{~mL}$ with $0.1 \%$ acetic acid, and an aliquot of $2 \mathrm{~mL}$ was then passed through a $0.2 \mu \mathrm{m}$ membrane filter (Adventec) for analysis by LC-MS/MS. For TTX analysis, 
the sample solutions were prepared by the Korean Food Standard (MFDS, 2021). Frozen samples were thawed, and each organ (2 g) from an individual specimen was homogenized and extracted with $8 \mathrm{~mL}$ of $0.1 \%$ acetic acid by boiling for $10 \mathrm{~min}$ and centrifuging at $7,000 \times \mathrm{g}$ for $10 \mathrm{~min}$ at $4{ }^{\circ} \mathrm{C}$. The supernatant was filled up to $10 \mathrm{~mL}$ with $0.1 \%$ acetic acid, then an aliquot of $2 \mathrm{~mL}$ was passed through a $0.2 \mu \mathrm{m}$ membrane filter for analysis by LC-MS/MS. Another $8 \mathrm{~mL}$ sample was used in the MBA.

\section{Mouse bioassay}

Following the AOAC Official Method 959.08 (2005), $1 \mathrm{~mL}$ of $\mathrm{HCl}$ extract was injected intraperitoneally into 17-20 g mice, and the times of death were recorded. The concentrations of PSTs were then calculated and presented as $\mu \mathrm{g} / 100 \mathrm{~g}$ STX eq sample using Sommer's Table. For TTX analysis, $1 \mathrm{~mL}$ of $0.1 \%$ acetic acid extract was injected into the abdominal cavity, and the times of death were recorded. The mouse unit (MU) was calculated according to the time of death and the body weight of each mouse.

\section{Liquid chromatograph-tandem mass spectrometry (LC-MS/ MS)}

Analysis of PSTs by LC-MS/MS was performed using selective reaction monitoring (SRM). The HPLC unit consisted of a Surveyor MS Pump Plus and Surveyor AS Plus (Thermo Electron, San Jose, CA, USA). A triple-quadrupole mass spectrometer (TSQ Quantum Discovery Max; Thermo Electron, San Jose, CA, USA) was used for mass detection. For toxin determination, SRM-chromatograms were recorded in positive ionization mode for the transitions listed in Table 1. In autosampler, tray temperature was $7^{\circ} \mathrm{C}$. These separations were performed on a TSK Gel-amide- 80 column $(250 \times 0.2 \mathrm{~mm}, 5 \mu \mathrm{m}$; Tosoh Bioscience, Tokyo, Japan) preceded by a guard column cartridge $(4.0 \times 0.2 \mathrm{~mm}$; Tosoh Bioscience $)$ and oven temperature was $35^{\circ} \mathrm{C}$. Eluents A (water) and B (acetonitrile-water, 95:5) each contained $2 \mathrm{mM}$ ammonium formate and $3.6 \mathrm{mM}$ formic acid. The analytic conditions were as described previously (Song et al., 2013). TTX analysis was performed using the same LC-MS/ MS system and column as PST analysis, with positive ionization mode and eluents A ( $0.1 \%$ formic acid) and B (methanol) as the linear gradient elution. With the aim of validation of the

Table 1. LC-MS/MS operating conditions for the analysis of PSTs and TTX

\begin{tabular}{|c|c|c|c|c|c|c|c|}
\hline & \multicolumn{4}{|l|}{ PSTs } & \multicolumn{3}{|l|}{ TTX } \\
\hline Spray voltage & \multicolumn{4}{|l|}{$5.0 \mathrm{kV}$} & \multicolumn{3}{|l|}{$3.5 \mathrm{kV}$} \\
\hline Capillary temp. & \multicolumn{4}{|l|}{$350^{\circ} \mathrm{C}$} & \multicolumn{3}{|l|}{$320^{\circ} \mathrm{C}$} \\
\hline Sheath gas & \multicolumn{4}{|l|}{17 (Arb) } & \multicolumn{3}{|l|}{50 (Arb) } \\
\hline Aux gas & \multicolumn{4}{|l|}{19 (Arb) } & \multicolumn{3}{|l|}{10 (Arb) } \\
\hline Polarity & \multicolumn{4}{|l|}{ Positive } & \multicolumn{3}{|l|}{ Positive } \\
\hline Detection & \multicolumn{4}{|c|}{ Selected reaction monitoring (SRM) } & \multicolumn{3}{|l|}{ SRM } \\
\hline \multirow[t]{13}{*}{ Mass spectrometer } & Toxins & Parent ion $(\mathrm{m} / \mathrm{z})$ & Fragment ion $(\mathrm{m} / \mathrm{z})$ & Collision energy (eV) & Parent ion $(\mathrm{m} / \mathrm{z})$ & Fragment ion (m/z) & Collision energy $(\mathrm{eV})$ \\
\hline & STX & 300 & 282 & 20 & \multirow[t]{3}{*}{320} & 302 & 35 \\
\hline & NEO & 316 & 298 & 20 & & 256 & 40 \\
\hline & GTX1 & 412 & 332 & 20 & & 162 & 40 \\
\hline & GTX2 & 396 & 316 & 20 & & & \\
\hline & GTX3 & 396 & 298 & 20 & & & \\
\hline & GTX4 & 412 & 314 & 20 & & & \\
\hline & GTX5 & 380 & 300 & 20 & & & \\
\hline & dcSTX & 257 & 196 & 20 & & & \\
\hline & dcGTX2 & 353 & 273 & 20 & & & \\
\hline & dcGTX3 & 353 & 335 & 20 & & & \\
\hline & $\mathrm{C} 1$ & 396 & 316 & 20 & & & \\
\hline & $\mathrm{C} 2$ & 396 & 298 & 20 & & & \\
\hline
\end{tabular}

LC-MS/MS, liquid chromatograph-mass spectrometer; PST, paralytic shellfish toxins; TTX, tetrodotoxin; STX, saxitoxin; NEO, neosaxitoxin; GTX, gonyautoxin; dcSTX, decarbamoylsaxitoxin; dcGTX, decarbamoylgonyautoxin; C, protogonuautoxin. 
analysis conditions, the mixed standard solution for PSTs were prepared so that it would become $0.001,0.01,0.05,0.1,0.5$, and $1.0 \mu \mathrm{g} / \mathrm{g}$. TTX standard also prepared $0.01,0.05,0.1,0.5$, and 1.0 $\mu \mathrm{g} / \mathrm{g}$. PSTs and TTX standard solution were diluted with 0.003 $\mathrm{N}$ hydrochloric acid and injection volume was $10 \mu \mathrm{L}$.

The limit of detection (LOD) was set to be $>3$ as signal to noise ratio $(\mathrm{S} / \mathrm{N})$ in the Xcalibur software. The limit of quantitation (LOQ) was determined at a concentration of LOD $\times 3$. The recovery (\%) of the test method was analyzed by treating the standard solution, which included base concentration in the samples of pufferfish muscle, through the same pre-treatment method $(n=5)$. The final concentration of $1.0 \mu \mathrm{g} / \mathrm{g}$ of the standard solutions. Matrix effect (\%) was calculated by repeated measurements by adding the sample extracts so that the each toxin standard became $1.0 \mu \mathrm{g} / \mathrm{g}$.

\section{Results and Discussions}

Takifugu pardalis and Takifugu niphobles samples collected between January and March 2014 from the coastal regions of Tongyeong were analyzed for TTX and PST levels using MBA and LC-MS/MS. The samples consisted of seven T. pardalis and seven T. niphobles, each of which was divided into three parts for the experiment: muscles, intestines, and liver. Gender differentiation was difficult because the gonads were not fully developed, and no related tests could be conducted.

We hypothesized that since TTX-bearing marine organ- isms possess PSTs and that PST-bearing organisms also possess TTX, both types of toxins were analyzed.

The toxicity of the $0.1 \mathrm{~N}$ hydrochloric acid extracts and $0.1 \%$ acetic acid extracts prepared from three organs of each specimen were analyzed by MBA. Most of the extracts killed mice with typical signs of TTX and PSTs. However, Ahmed (1991) reported that TTX and PSTs are both neurotoxins and produce similar symptoms in mammals, yet the traditional MBA monitoring method for toxins does not distinguish between TTX and PSTs. Therefore, we detected each toxin by LC-MS/MS for superior accuracy.

For TTX analysis, a TTX single standard solution was used in the SRM mode with the parent ion set as $\mathrm{m} / \mathrm{z} 320$ and the fragment ions as $\mathrm{m} / \mathrm{z}$ 302, 256, and 162. As a result, the two types of puffer fish samples yielded a chromatogram identical to the standard solution at a retention time of $3.94 \mathrm{~min}$ (Fig. 1). Additionally, a simultaneous analysis of the standard solution mixtures of 12 PST components (C1, C2, dcGTX2, dcGTX3, dcSTX, GTX1, GTX2, GTX3, GTX4, GTX5, NEO, and STX) showed that all toxins were separated within $8 \mathrm{~min}$ (Fig. 2); all these toxins, except dcSTX and STX, were detected in the puffer fish samples.

This study used a combination of MS/MS and hydrophilic interaction liquid chromatography (HILIC) in the analysis. HILIC is a very useful method for the separation of polar compounds (Alpert, 1990). This method is advantageous because substances are separated by the interaction of the hydrophilic

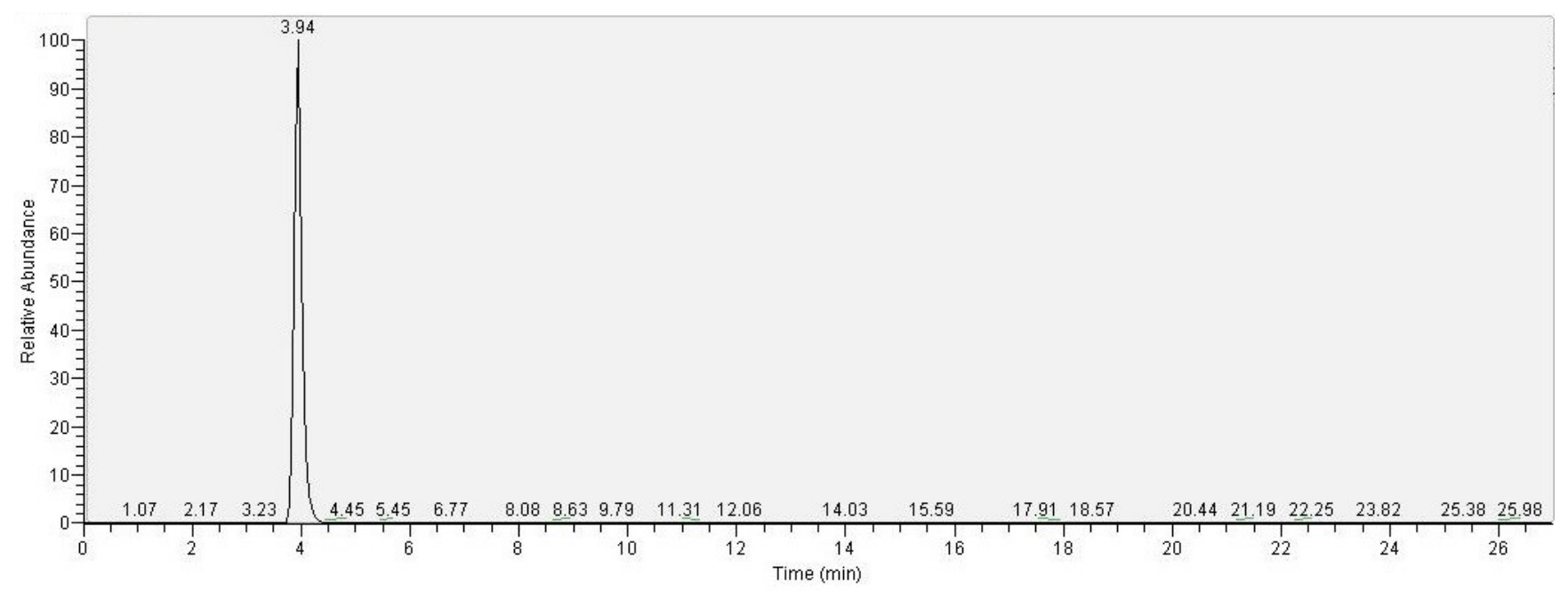

Fig. 1. LC-MS/MS chromatogram of tetrodotoxin (TTX) standard solution $(1 \mu \mathrm{g} / \mathrm{g})$. LC-MS/MS, liquid chromatograph-tandem mass spectrometry. 

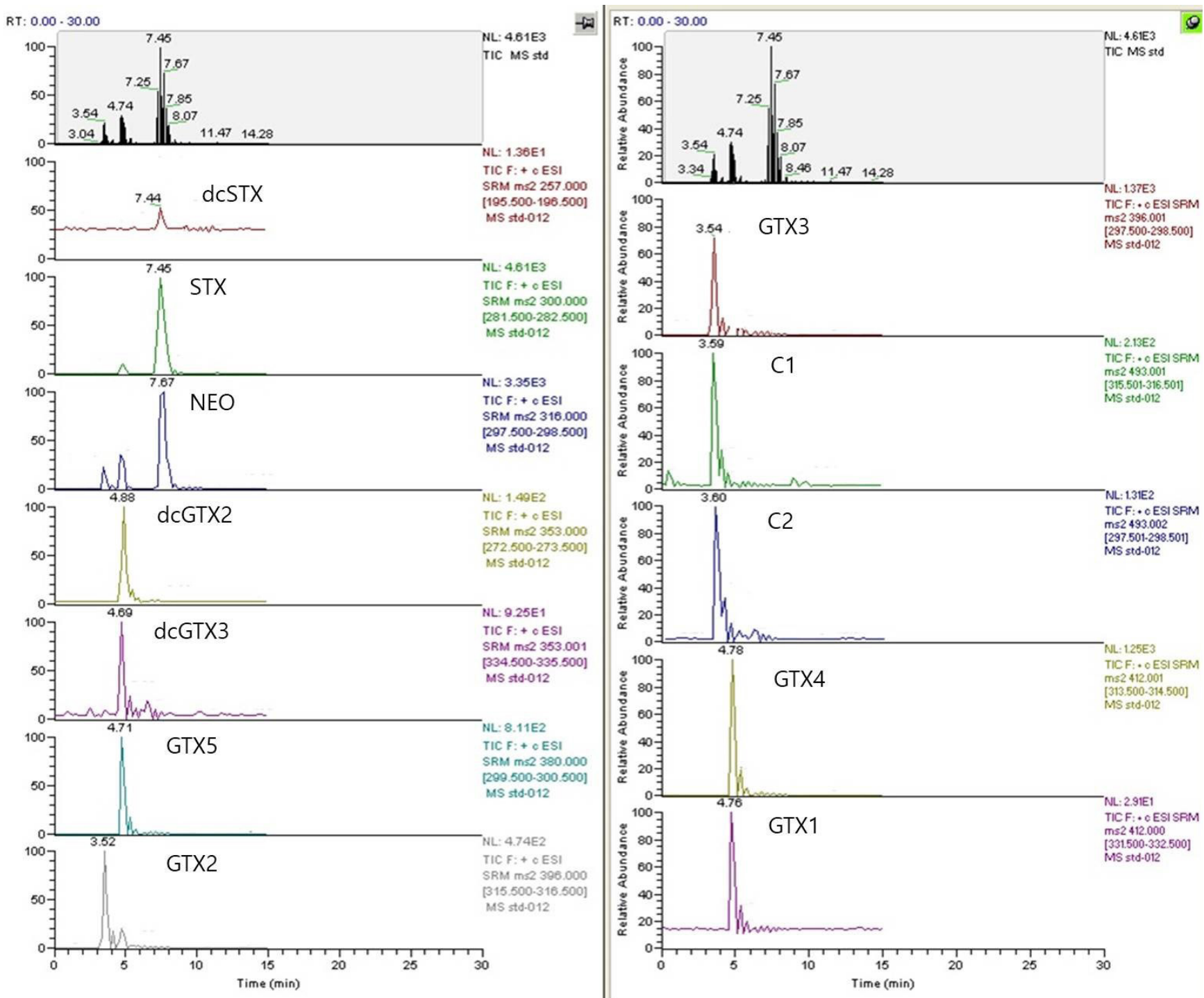

Fig. 2. LC-MS/MS chromatogram paralytic shellfish toxins (PSTs) reference standard working solution (0.1 $\boldsymbol{\mu g} / \mathbf{g})$. LC-MS/MS, liquid chromatograph-tandem mass spectrometry; STX, saxitoxin; NEO, neosaxitoxin ; GTX, gonyautoxin; C, protogonuautoxin.

column and the mobile phase; ionization efficacy is not diminished because the mobile phase does not contain ion pair reagents, and PSTs can be quickly and selectively analyzed simultaneously (Dell'Aversano et al., 2005).

The validation of the analysis conditions, the mixed standard solution for 12 PSTs were prepared so that it would become range of $0.001-1.0 \mu \mathrm{g} / \mathrm{g}$. The correlation coefficient $\left(\mathrm{r}^{2}\right)$ of 12 PSTs standard was above 0.99 , which showed a good linearity in each concentration range.

LOD for STX, GTX1, GTX3, GTX4, GTX5, dcSTX, and C1 was $0.001 \mu \mathrm{g} / \mathrm{g}$, besides, NEO, GTX2, dcGTX2, dcGTX3, and $\mathrm{C} 2$ was $0.01 \mu \mathrm{g} / \mathrm{g}$, when $\mathrm{S} / \mathrm{N}$ was assumed as $>3$, and LOQ was $0.003 \mu \mathrm{g} / \mathrm{g}$ and $0.03 \mu \mathrm{g} / \mathrm{g}$, respectively. And to evaluated recovery (\%), the standard solution of 12 PSTs mix were added to pufferfish muscle such that the final concentration of $1 \mu \mathrm{g} /$ g. Then the spiked samples were treated in the same method of sample pre treatment and analyzed. Determined recovery (\%) of samples was in the range of $65.2 \%-93.7 \%$ for 12 PSTs standard. The results showed that $\mathrm{C}$ toxins was lower than other toxins. This is thought to be due to interference by salt that was not eliminated by the pre treatment process. Dell'Aversano et al. (2005) and Song et al. (2013) were also showed that salt con- 
tained in crude extracts can partially inhibit $\mathrm{C}$ toxins ionization. In addition, the established methods of analysis was almost free from the effect of pufferfish matrixes.

Meanwhile, the correlation coefficient $\left(r^{2}\right)$ of TTX is 0.99 . LOD and LOQ were $0.01 \mu \mathrm{g} / \mathrm{g}$ and $0.03 \mu \mathrm{g} / \mathrm{g}$, respectively. It was determined that recovery (\%) of tested samples was more than $90 \%$, and there was not matrix effect. Determined TTX pre treatment method was satisfactory for pufferfish.

Table 2 lists the results of the analysis of seven specimens of T. pardalis and T. niphobles, each divided into muscles, intestines, and liver and examined for TTX. In T. pardalis, the TTX levels were within the range of $1.3-1.6 \mu \mathrm{g} / \mathrm{g}$ in the muscles, $18.8-49.8 \mu \mathrm{g} / \mathrm{g}$ in the intestines, and 23.3-96.8 $\mu \mathrm{g} / \mathrm{g}$ in the liver. In the T. niphobles, the TTX levels were within the range of $2.0-4.5 \mu \mathrm{g} / \mathrm{g}$ in the muscles, $23.9-71.5 \mu \mathrm{g} / \mathrm{g}$ in the intestines, and $28.1-114.8 \mu \mathrm{g} / \mathrm{g}$ in the liver. Both species showed the lowest detected levels of TTX in the muscles, which is the most commonly consumed portion; the concentrations were the highest in the liver, which is non-edible. This is consistent with the results of previous studies by Jang \& Yotsu-Yamashita (2006), who reported a high degree of toxicity in the T. pardalis liver, and Itoi et al. (2012), who showed a high degree of toxicity in the T. niphobles liver. However, previous studies of various types of puffer fish reported differences in toxicity among the same species, depending on the area in which they were caught (Kim et al., 2006; Kim et al., 2007; Kim et al., 2008).

In biological experiments involving mice and conducted from the perspective of food hygiene, concentrations of TTX less than $10 \mathrm{MU} / \mathrm{g}$ are not considered harmful; this is in contrast to the TTX detection limits (Kawabata, 1978); 1 MU of TTX is $0.178 \mu \mathrm{g}$ (Jen et al., 2008). In the current study, when converted to MU, all levels in the muscles were less than 10 MU/g; however, as the TTX levels detected in the intestines and liver were more than 10 times that value, it is thought that these parts are not suitable for consumption.

Table 3 shows the results of the PST detection from the three sample parts using LC-MS/MS. The value of each toxin detected was quantified and converted into saxitoxin equivalents (Table 4; Luckas et al., 2003) and the highest value was noted. In Korea, the maximum permitted PST limit in foods is $80 \mu \mathrm{g} / 100 \mathrm{~g}$ or $0.8 \mu \mathrm{g} / \mathrm{g}$ (KFDA, 2021).

When the toxin levels in each part were compared, both types of puffer fish showed low levels of toxin in the muscles. PSTs were detected mainly in the intestines, and dcGTX3 levels were the most prevalent component for both species examined. However, the relative toxicity of dcGTX3 was 0.3766 , which was lower than that of STX (relative toxicity 1). Low levels of toxins were also detected in the liver, with dcGTX3 being the most prevalent component in T. niphobles.

In the TTX analysis, higher concentrations were detected in the liver compared with in the intestines, whereas PSTs were higher in the intestines. Because neither TTX nor PSTs were detected at high levels in the muscles, consumption of this specific part of the puffer fish is considered safe.

The toxicity profile of the detected PSTs is illustrated in Fig. 3. When the PST composition was compared between species, dcGTX3 was the most prevalent component in the panther puffer, and dcSTX, STX, GTX1, GTX4, and C2 were not detected. In T. niphobles, the most prevalent component was dcGTX3, and dcSTX, STX, and NEO were not detected. GTX1, GTX2, and GTX4 levels were higher in T. niphobles than in T. pardalis, and small amounts of $\mathrm{C} 1$ and $\mathrm{C} 2$ were also detected in T. niphobles. In a previous study of two species of fresh water puffer fish from Bangladesh (Tetrodon cutcutia and Chelonodon patoca), STX, dcSTX, GTX2, GTX3, dcGTX2, and dcGTX3 were detected (Zaman et al., 1997). In another study, dcSTX,

Table 2. Comparison of tetrodotoxin (TTX) concentrations $(\mu \mathrm{g} / \mathrm{g})$ in muscle, intestine and liver of Takifugu pardalis and Takifugu niphobles by LC-MS/MS

\begin{tabular}{|c|c|c|c|c|}
\hline \multirow[t]{2}{*}{ Puffer fish } & \multirow[t]{2}{*}{ Sampling date } & \multicolumn{3}{|l|}{ Toxicity ( $\mu \mathrm{g} / \mathrm{g})$} \\
\hline & & Muscle (Mean \pm SD) & Intestine (Mean \pm SD) & Liver (Mean \pm SD) \\
\hline \multirow[t]{3}{*}{ Takifugu pardalis } & Jan. $2014(n=7)$ & $1.3 \pm 2.8$ & $18.8 \pm 16.5$ & $23.3 \pm 24.7$ \\
\hline & Feb. $2014(n=7)$ & $1.6 \pm 1.9$ & $31.4 \pm 24.7$ & $82.0 \pm 54.2$ \\
\hline & Mar. $2014(n=7)$ & $1.4 \pm 2.2$ & $49.8 \pm 38.6$ & $96.8 \pm 42.0$ \\
\hline \multirow[t]{3}{*}{ Takifugu niphobles } & Jan. $2014(n=7)$ & $2.0 \pm 3.2$ & $23.9 \pm 25.0$ & $28.1 \pm 15.8$ \\
\hline & Feb. $2014(n=7)$ & $4.5 \pm 2.7$ & $71.5 \pm 22.8$ & $114.8 \pm 87.3$ \\
\hline & Mar. $2014(n=7)$ & $1.6 \pm 1.4$ & $25.9 \pm 14.4$ & $39.9 \pm 32.5$ \\
\hline
\end{tabular}

LC-MS/MS, liquid chromatograph-tandem mass spectrometry. 
Table 3. Highest concentrations of paralytic shellfish toxins (PSTs) measured by LC-MS/MS in the liver, intestine and muscle of Takifugu pardalis and Takifugu niphobles

\begin{tabular}{|c|c|c|c|c|c|c|}
\hline \multirow[t]{3}{*}{ Toxins } & \multicolumn{6}{|c|}{ Toxin contents ( $\mu \mathrm{g} / \mathrm{g}$ STX equiv.) } \\
\hline & \multicolumn{3}{|c|}{ Takifugu pardalis } & \multicolumn{3}{|c|}{ Takifugu niphobles } \\
\hline & Muscle & Intestine & Liver & Muscle & Intestine & Liver \\
\hline dcSTX & ND & ND & ND & ND & ND & ND \\
\hline STX & ND & ND & ND & ND & ND & ND \\
\hline NEO & ND & ND & ND & 0.004 & 0.148 & ND \\
\hline dcGTX2 & ND & 0.047 & ND & ND & 0.147 & 0.001 \\
\hline dcGTX3 & 0.084 & 0.323 & 0.070 & 0.044 & 0.348 & 0.270 \\
\hline GTX1 & ND & 0.231 & ND & ND & ND & ND \\
\hline GTX2 & ND & 0.219 & ND & ND & 0.042 & ND \\
\hline GTX3 & 0.001 & 0.051 & 0.022 & ND & 0.053 & 0.010 \\
\hline GTX4 & ND & 0.138 & 0.008 & ND & ND & ND \\
\hline GTX5 & ND & 0.044 & 0.005 & ND & 0.031 & ND \\
\hline C1 & 0.001 & 0.001 & ND & ND & 0.002 & 0.001 \\
\hline $\mathrm{C} 2$ & 0.001 & 0.001 & ND & ND & 0.003 & ND \\
\hline
\end{tabular}

LC-MS/MS, liquid chromatograph-tandem mass spectrometry; dcSTX, decarbamoylsaxitoxin; ND, not detected; STX, saxitoxin; NEO, neosaxitoxin; dcGTX2, decarbamoylgonyautoxin-2; dcGTX3, decarbamoylgonyautoxin-3; GTX1, gonyautoxin-1; GTX2, gonyautoxin-2; GTX3, gonyautoxin-3; GTX4, gonyautoxin-4; GTX5, gonyautoxin-5; C1, N-sulfocarbamoylgonyautoxin-C1; 2 , N-sulfocarbamoylgonyautoxin-C2.

Table 4. Relative toxicity of paralytic shellfish toxins (PSTs)

\begin{tabular}{llll}
\hline Toxin & ReTx & Toxin & ReTx \\
\hline STX & 1.0000 & GTX5 & 0.0644 \\
NEO & 0.9243 & dcSTX & 0.5131 \\
GTX1 & 0.9940 & dcGTX2 & 0.1538 \\
GTX2 & 0.3592 & dcGTX3 & 0.3766 \\
GTX3 & 0.6379 & C1 & 0.0060 \\
GTX4 & 0.7261 & C2 & 0.0963 \\
\hline
\end{tabular}

STX, saxitoxin; GTX5, gonyautoxin-5; NEO, neosaxitoxin; dCSTX, decarbamoylsaxitoxin; GTX1, gonyautoxin-1; dcGTX2, decarbamoylgonyautoxin-2; GTX2, gonyautoxin-2; dcGTX3, decarbamoylgonyautoxin-3; GTX3, gonyautoxin-3; C1, N-sulfocarbamoylgonyautoxin-C1; GTX4, gonyautoxin-4; C2, N-sulfocarbamoylgonyautoxin-C2.

neoSTX, and GTX5 were detected in seven species of marine puffers from the Philippines (Sato et al., 2000). Taken together, these results indicate that there is no characteristic PST profile for puffer fish. As mentioned, the composition and content of toxins vary according to habitat, environmental conditions (e.g., freshwater or marine water), and puffer species.

Additionally, when PSTs were calculated as saxitoxin equivalents, the levels were all lower than $0.5 \mu \mathrm{g} / \mathrm{g}$, which is below the permitted maximum standard of $0.8 \mu \mathrm{g} / \mathrm{g}$. This suggests that the toxicity of T. pardalis and T. niphobles from the southern coast of Korea is due mainly to TTX and that PSTs do not exert an effect. However, it is low enough in muscle not to be a hazard but the other parts could be hazardous to health and have to be removed from contact with the muscle first.

In summary, the current findings demonstrate that TTX was the major toxin in T. pardalis and T. niphobles inhabiting Korean coastal areas and that PSTs were minor toxins. It indicates that the causes of TTX-induced toxicity in aquatic animals, such as puffer fish, are identical to those of PST-induced toxicity. PSTs are widely known as toxins produced by dinoflagellates, which are a type of phytoplankton. TTX is produced by marine bacteria (Lago et al., 2015). Also, the amount of TTX accumulate in puffer fish through a food chain including bacteria, plankton, invertebrates and fish (Lago et al., 2015). However, TTX has been isolated in significant amounts from the representative PST-producer, Alexandrium tamarense (Kodama et al., 1996; Schantz, 1986). In addition to, Lago et al. (2015) and Sato et al. $(2000,1998)$ stated that PSTs are also produced by bacteria. In the marine ecosystem, phytoplankton and bacteria produce both PSTs and TTX, which is consistent with the results of the current study.

In future studies, we plan to investigate PST accumulation in other TTX-bearing puffer fish species inhabiting Korean coastal areas. Additionally, we will examine the mechanisms of TTX and PST accumulation by identifying the organisms responsible for puffer toxicity in Korean coastal areas. 

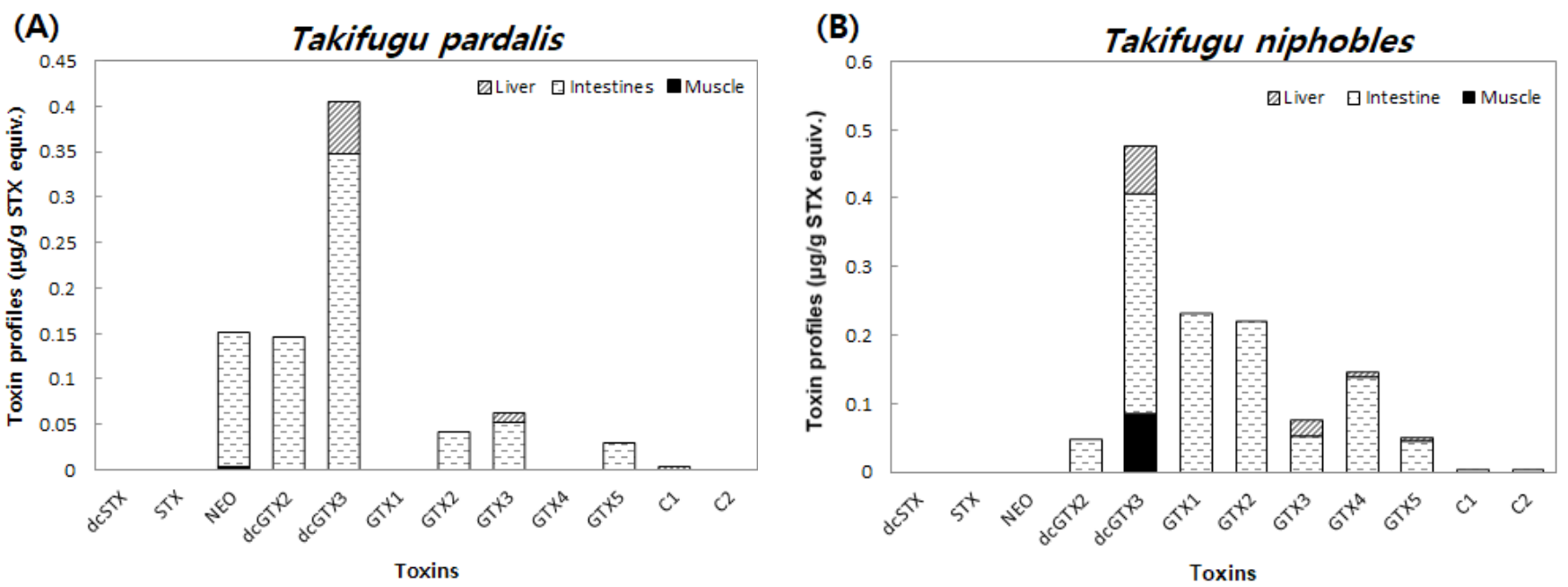

Fig. 3. Composition of paralytic shellfish toxins (PSTs) congeners measured by LC-MS/MS in the liver, intestine and muscle of Takifugu pardalis and Takifugu niphobles. STX, saxitoxin; NEO, neosaxitoxin; GTX, gonyautoxin; C, protogonuautoxin; LC-MS/MS, liquid chromatograph-tandem mass spectrometry.

\section{Conclusion}

This study was hypothesized that since TTX-bearing marine organisms possess PSTs and that PST-bearing organisms also possess TTX, both types of toxins were analyzed. Takifugu pardalis and Takifugu niphobles samples were analyzed for TTX and PST levels using MBA and LC-MS/MS. As a result of the validation of the established method in this study, it was an effective method for the quantification of TTX and PSTs. The results of the present study showed that the lowest detected levels of TTX in the muscles, which is the most commonly consumed portion; the concentrations were the highest in the liver, which in non-edible. The PST levels in each part were compared, that was detected mainly in the intestines, and dcGTX3 levels were the most prevalent component for both species examined. This result signified in the marine ecosystem, phytoplankton and bacteria produce both PSTs and TTX. Additionally, it is low enough in muscle not to be a hazard but the other parts could be hazardous to health and have to be removed from contact with the muscle.

\section{Competing interests}

No potential conflict of interest relevant to this article was reported.

\section{Funding sources}

This work was supported by a grant from the National Institute of Fisheries Science (R2021060).

\section{Acknowledgements}

Not applicable.

\section{Availability of data and materials}

All data sets generated and/or analyzed during the current study are available with the corresponding author.

\section{Ethics approval and consent to participate}

Ethics guidelines for the use of animal care were followed.

\section{ORCID}

Ka Jeong Lee https://orcid.org/0000-0001-9273-8384

Kwang Soo Ha https://orcid.org/0000-0002-8325-9928

Yeoun Joong Jung https://orcid.org/0000-0002-3040-6584 Jong Soo Mok https://orcid.org/0000-0003-2066-0826 Kwang Tae Son https://orcid.org/0000-0002-7294-3345 Hee Chung Lee https://orcid.org/0000-0002-3508-8319 Ji Hoe Kim https://orcid.org/0000-0003-0944-2385

\section{References}

Abbott JP, Flewelling LJ, Landsberg JH. Saxitoxin monitoring in three species of Florida puffer fish. Harmful Algae. 2009;8:343-8 
Ahmed FE. Seafood safety. Washington, DC: National Academy Press; 1991.

Alpert AJ. Hydrophilic-interaction chromatography for the separation of peptides, nucleic acids and other polar compounds. J Chromatogr A. 1990;499:177-96.

AOAC [Association of Official Analytical Chemists] International. Official methods of analysis of AOAC International. 18th ed. Gaithersburg, MD: AOAC International; 2005.

Bricelj VM, Shumway SE. Paralytic shellfish toxins in bivalve molluscs: occurrence, transfer kinetics, and biotransformation. Rev Fish Sci. 1998;6:315-83.

Dell'Aversano C, Hess P, Quilliam MA. Hydrophilic interaction liquid chromatography-mass spectrometry for the analysis of paralytic shellfish poisoning (PSP) toxins. J Chromatogr A. 2005; 1081:190-201.

Itoi S, Yoshikawa S, Tatsuno R, Suzuki M, Asahina K, Yamamoto $S$, et al. Difference in the localization of tetrodotoxin between the female and male pufferfish Takifugu niphobles, during spawning. Toxicon. 2012;60:1000-4.

Jang J, Yotsu-Yamashita M. Distribution of tetrodotoxin, saxitoxin, and their analogs among tissues of the puffer fish Fugu pardalis. Toxicon. 2006;48:980-7.

Jen HC, Lin SJ, Tsai YH, Chen CH, Lin ZC, Hwang DF. Tetrodotoxin poisoning evidenced by solid-phase extraction combining with liquid chromatography-tandem mass spectrometry. J Chromatogr B. 2008;871:95-100.

Kao CY. Structure-activity relations of tetrodotoxin, saxitoxin, and analogues. Ann N Y Acad Sci. 1986;479:52-67.

Kawabata T. Puffer Toxin. In: Ministry of Health and Welfare, editors. The manuals for the methods of food sanitation tests II. Tokyo: Japan Food Hygienic Association; 1978. p.232-40.

Kim JH, Gong QL, Mok JS, Min JG, Lee TS, Park JH. Characteristics of puffer fish poisoning outbreaks in Korea (19912002). J Food Hyg Saf. 2003;18:133-8.

Kim JH, Mok JS, Son KT, Kim JG, Jo MR, Kim PH, et al. Toxicity of the puffer fish, Takifugu xanthopterus (Kkachibok) and Takifugu stictonotus (Kkachilbok) from coastal area of Korea. Korean J Fish Aquac Sci. 2007;40:276-81.

Kim JH, Son KT, Mok JS, Kim JK, Jo MR, Shim KB, et al. Toxicity of puffer fish, Arothron firmamentum (Byeolbok) and Lagocephalus spp. in Korea. Korean J Fish Aquac Sci. 2008;41:309-14.

Kim JH, Son KT, Mok JS, Oh EG, Kim JK, Lee TS. Toxicity of the puffer fish Takifugu porphyreus and Takifugu rubripes from coastal areas of Korea. Korean J Fish Aquac Sci. 2006;39:447-53.

Kodama M, Ogata T, Noguchi T, Maruyama J, Hashimoto K. Occurrence of saxitoxin and other toxins in the liver of the pufferfish Takifugu pardalis. Toxicon. 1983;21:897-900.

Kodama M, Sato S, Sakamoto S, Ogata T. Occurrence of tetrodotoxin in Alexandrium tamarense, a causative dinoflagellate of paralytic shellfish poisoning. Toxicon. 1996;34:1101-5.

Lago J, Rodríguez LP, Blanco L, Vieites JM, Cabado AG. Tetrodotoxin, an extremely potent marine neurotoxin: distribution, toxicity, origin and therapeutical uses. Mar Drugs. 2015;13:6384-406.

Luckas B, Hummert C, Oshima Y. Analytical methods for paralytic shellfish poisons. In: Hallegraeff GM, Anderson DM, Cembella AD, editors. Manual on harmful marine microalgae. Paris, France: UNESCO; 2003.

Ministry of Food and Drug Safety [MFDS]. Food Code. Chapter 2. Common standards and specifications for general foods; Cheongju, Korea: MFDS; 2021.

Mortensen AM. Massive fish mortalities in the Faroe islands caused by a Gonyaulax excavate red tide. In: Anderson DM, White A, Baden DG, editors. Toxic dinoflagellates. New York, NY: Elsevier, 1985. p. 165-70.

Nakashima K, Arakawa O, Taniyama S, Nonaka M, Takatani T, Yamamori K, et al. Occurrence of saxitoxins as a major toxin in the ovary of a marine puffer Arothron firmamentum. Toxicon. 2004;43:207-12.

Negri A, Llewellyn L. Comparative analyses by HPLC and the sodium channel and saxiphilin $3 \mathrm{H}$-saxitoxin receptor assays for paralytic shellfish toxins in crustaceans and molluscs from tropical North West Australia. Toxicon. 1998;36:283-98.

Sato S, Ogata T, Borja V, Gonzales C, Fukuyo Y, Kodama M. Frequent occurrence of paralytic shellfish poisoning toxins as dominant toxins in marine puffer from tropical water. Toxicon. 2000;38:1101-9.

Sato S, Ogata T, Kodama M. Trace amounts of saxitoxins in the viscera of chum salmon Oncorhynchus keta. Mar Ecol Prog Ser. 1998;175:295-8.

Schantz EJ. Chemistry and biology of saxitoxin and related toxins. Ann N Y Acad Sci. 1986;479:15-23.

Sephton DH, Haya K, Martin JL, LeGresley MM, Page FH. Paralytic shellfish toxins in zooplankton, mussels, lobsters and caged Atlantic salmon, Salmo salar, during a bloom of Alexandrium fundyense off Grand Manan island, in the Bay 
of Fundy. Harmful Algae. 2007;6:745-58.

Song KC, Lee KJ, Yu HS, Mok JS, Kim JH, Lim KS, et al. Paralytic shellfish poisoning (PSP) analysis using liquid chromatography-tandem mass spectrometry. Korean J Fish Aquat Sci. 2013;46:154-9.

White AW. Sensitivity of marine fishes to toxins from the redtide dinoflagellate Gonyaulax excavate and implications for fish kills. Mar Biol. 1981;65:255-60.

Zaman L, Arakawa O, Shimosu A, Onoue Y. Occurrence of paralytic shellfish poison in Bangladeshi freshwater puffers. Toxicon. 1997;35:423-31. 